\title{
Relationship between physical exercise and the most varied forms of dyskinesia
}

\author{
Ana Elisa Speck ${ }^{1,2}$ (D) , Aderbal S Aguiar Jr. ${ }^{1}$ \\ ${ }^{1}$ Universidade Federal de Santa Catarina, Departamento de Ciências da Saúde, Laboratório \\ Biologia do Exercício Físico, Araranguá, SC, Brasil; ${ }^{2}$ Universidade Federal de Santa Catarina, \\ Departamento de Farmacologia, Laboratório Experimental de Doenças Neurodegenerativas, \\ Florianópolis, SC, Brasil.
}

Associate Editor: Almir Vieira Dibai Filho, UFMA, São Luiz, MA, Brazil

\begin{abstract}
Aim: Dyskinesia is a hyperkinetic abnormal involuntary movement (AIM), like chorea, dystonia, athetosis, and ballism. AIM can occur in Levodopa-induced dyskinesia (LID) in Parkinson's disease (PD), tardive dyskinesia (TD) schizophrenia, and paroxysmal dyskinesias (PxDs). This review describes the effects of physical activity and exercise adaptation (e.g., rehabilitation) in the most varied forms of dyskinesias in an attempt to provide a comprehensive understanding of the role of physical exercise on this disorder. Methods: English-language articles available in the database PubMed electronics were examined. The following indexes were adopted with different combinations: LID and exercise; TD and exercise PED and exercise. Manual searches were performed in the references of the articles related to the chosen topic. Results. The relationship between many types of dyskinesia and exercise is poorly explored. The practice of physical activity showed antidyskinetic effects in Parkinson's LID, with well-described the biological mechanisms. Conclusion: Acute exercise does not modify the abnormal respiratory patterns in TD, and it reveals a normal response to progressive training and inspiratory time. Sustained walking or running may induce a type of paroxysmal dyskinesia in the healthy subjects, which was explored by us in this review.
\end{abstract}

Keywords: dyskinesia, physical exercise, Levodopa-induced dyskinesia, tardive dyskinesia and paroxysmal dyskinesia.

\section{Introduction}

Dyskinesia refers to various unintentional, involuntary, rhythmic, and uncontrollable movements that can diminish or impair voluntary movements. These movements include spasms, twists, chorea, dystonia, or general restlessness in the upper body as well as trunk or lower extremities $^{1,2}$. Muscle incoordination can also occur internally, particularly with the respiratory muscles, and it may often understudy ${ }^{3,4}$. Besides, this motor disorder can affect each one in different forms, considering time, frequency, and severity. For example, it can significantly interfere with the daily life activities (ADLs) of the patients, or it may be light and almost invisible. In general, the movements are similar to a dance, known as chorea; however, sometimes they are occasionally known as dystonia, which causes sustained spasms and involuntary muscle contractions. Dystonia is slower, painful, and contorted, forcing the body into unnatural postures. Choreic movements and dystonias often overlap and can co-occur ${ }^{5}$.

Dyskinesia may occur in Parkinson's disease (PD) and may result from the disease process itself more as a consequence of the side effect of levodopa medication used to treat the disease symptoms ${ }^{1,6,7}$. This abnormal involuntary movement (AIM) after L-DOPA treatment is known as a L-DOPA-induced dyskinesia (LID). The LID occurs when the plasma levels of the drugs decrease in the morning (dyskinesia of drugs "off") or during the day when the medication is working (dyskinesia of drugs) $)^{8,9}$. The most common types of dyskinesia in PD include chorea, ballism, dystonia, and myoclonus. Several individuals would rather be on dyskinesia than off without dyskinesia. The dyskinesia peak occurs when dopamine $(\mathrm{AD})$, reaches the maximum plasma level "dyskinesia with maximum dose."

In contrast, dyskinesia can also happen when levodopa begins to end its effect. It is known as dysphasic dyskinesia. Different parts of the body may be affected, the most common areas being limbs and trunk ${ }^{8}$. Dyskinesia can also occur in psychotic patients due to the use of medications (antipsychotics or other drugs). Psychotic patients show hyperkinetic dyskinesia like "grimaces" and "irregular movements of the tongue and lips". In this case, tardive dyskinesia (TD) is a syndrome that includes a variety of movement disorders.

Moreover, certain established risk factors are responsible for developing TD. Age seems consistently associated with the development, persistence, and pro- 
gression of TD. Women appear to be at an increased risk for $\mathrm{TD}^{10}$. Spontaneous dyskinesia in medication-control patients with schizophrenia, and rarely, in the general population, have been reported ${ }^{11,12}$. The defining characteristics of TD include its delayed onset, hence the name "tardive," signifying a delay of weeks to months until further symptoms appear, and may lead to dyskinetic AIM. Depending on the severity, TD can have an adverse functional impact in patients' lives that can be debilitating, stigmatizing, and associated with increased mortality.

Paroxysmal dyskinesias (PxDs) are considered a hyperkinetic movement disorder defined by their episodic nature ${ }^{13}$. Patients PxDs present with repeated episodes of this order (dystonia, chorea, or both) that have a sudden onset, and after a duration that ranges from seconds to days. PxDs may be primary or secondary, are often associated with genetic causes at the primary stage. PxDs triggered by sudden body movements, as well as paroxysmal exercise-induced dyskinesia (PED) that is triggered by continuous physical effort. PED is by attacks of dystonia and chorea triggered by prolonged physical exercise, typically lasting for 5-30 $\mathrm{min}^{14}$. The attack often starts in the body part involved in the physical activity. Paroxysmal nonkinesigenic dyskinesia (PNKD) is often provoked by consumption of coffee, alcohol, or by stress ${ }^{15,16}$. Several PxDs can be comorbid with other neurological disorders that are suggestive of an underlying channelopathy, such as epilepsy and migraine $e^{17,18}$.

Physical exercise can modify these different types of dyskinesias in various ways. In this review, we identified varied dyskinesias and their relationship with physical activity in clinical studies and experimental models.
Despite strong evidence about the benefits of physical exercise in LID, we could not find the same evidence in other types of dyskinesias such as TD and PxDs. After prolonged drug treatment, TD patients have weight gain, risk of falling, and respiratory dyskinesia while physical exercise mitigates these problems, unless respiratory dyskinesia.

Interestingly, unlike LID, physical exercise in patients with PED can activate dyskinesia. Besides, we attempted to review the evidence reported in clinical studies and experimental models to provide a comprehensive understanding of the role of physical exercise.

\section{Material and methods}

It is a narrative review, the National Library of Medicine (PubMed) electronic database used as a search tool. For the search, we used different terms: L-DOPA induced dyskinesia, tardive dyskinesia, and paroxysmal dyskinesia, all of these terms with exercise, physical activity, or rehabilitation. Additional manual searches were performed from the references found. The language for the search was English, with the availability between 1977 until 2018. The exclusion criteria were review papers, clinical and experimental papers that did not have relevant content, and articles that did not address physical activity and motor activity.

\section{Selection results}

In total, there were one hundred and sixty-two articles (Figure 1), of which exclusively 25 were original articles that focused on the relationship between exercise or

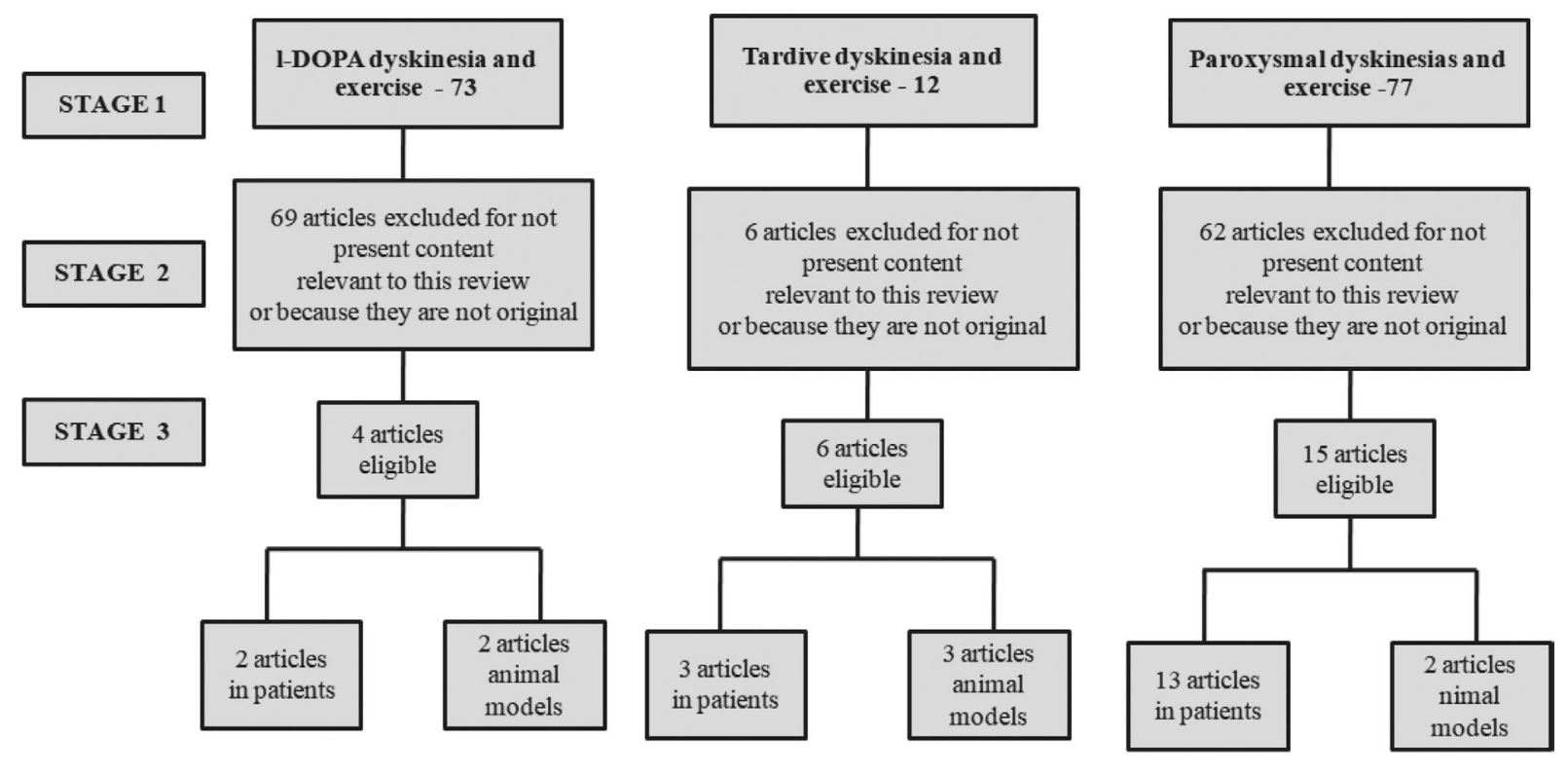

Figure 1 - Flow diagram of the selection process. 
physical activity and many forms of dyskinesias. The clinical and experimental details of these 25 original articles, it is described in Tables 1, 2, and 3.

\section{L-DOPA-induced dyskinesia and exercise}

The treatment of PD is a complex issue due to the progression of the disease and a set of motor and nonmotor signs combined with late side effects after therapeutic interventions. Although there are still no approved treatments to reduce disease progression, surgical alternatives and other approaches, such as physical exercise and physical therapy, are available. As it is well known DA does not cross the barrier hematoencephalic while LDOPA (L-3,4 dihydroxyphenylalanine) does; thus, it is the primary pharmacological treatment. The L-DOPA restablishes the dopaminergic neurotransmission and decreases the motor symptoms ${ }^{19-21}$. The clinical use of L-DOPA in PD began during the 1960s; it is still the most effective therapy to attenuate PD cardinal motor symptoms ${ }^{22}$. Motor dysfunctions are the main target of pharmacological treatment, with L-DOPA being the most effective drug $^{23}$. The main side effect of L-DOPA treatment is the development of dyskinesia and motor fluctuations. Thus, the objective of current physical exercise researchers is to prolong the antiparkinsonian effects of L-DOPA to improve the patient's quality of life.

The other therapeutic strategy includes cell transplant and deep brain stimulation (DBS) ${ }^{24}$. More recently, the continuous administration of levodopa-carbidopa intestinal gel (LCIG), reduces the variability of dopamine plasmatic and improves motor complications associated with chronic oral levodopa treatment ${ }^{25}$. Previous studies have demonstrated that LCIG therapy reduced "Off" time and dyskinesia as well as improved the patient's ability to perform ADLs and their nonmotor symptoms ${ }^{26}$, improving the quality of life of de patients.

Actually, besides all drugs that exist for the treatment of PD, the L-DOPA remains the most effective treatment for motor symptoms of PD. Yet, the effects of physical exercise on L-DOPA treatment still poor understood. For example, in animal models, running training for three weeks increases the synthesis and release of DA in DP in the C57BL/6 mice model of PD treated with a low dose of L-DOPA $(5 \mathrm{mg} / \mathrm{kg})^{27,28}$. Besides, physical exercise may increase the mRNA levels of the receptor dopaminergic neurons of the D2 type in the striatum after treadmill exercise for 30 days in mice treated with MPTP $^{29}$. Mice treated with MPTP and trained for six weeks in the treadmill revealed an increase in the expression of striatal D2 receptors showing the exercise-induced adaptations to dopaminergic neurotransmission ${ }^{30}$.

Physical exercise in PD patients, as in the rehabilitation strategy, shows an antidyskinetic effect. A summary of the studies is shown in Table 1. The results of a clinical trial showed a decreased dyskinesia in PD patients after intensive rehabilitation treatment ( $2 \mathrm{x}$ day) for four weeks, five days a week ${ }^{31}$. This intensive rehabilitation protocol (which comprised gait training exercises, treadmill, $2 \times$ per day) resulted in a substantial reduction in dyskinesia. However, another group of the patients who did less intense rehabilitation (once a day), had more modest decreases in LID score (Figure 2). This same research group and in a 6-month follow-up study demonstrated that this intensive rehabilitation protocol maintains the improvement in dyskinesia score, as well as the UPDRS scale, and can reduce the dose of L-DOPA for six months after treatment ${ }^{32}$.

Aguiar et $\mathrm{al}^{33}$ published the first research showing the antidiskinetic effects of physical exercise in animal models (C57BL/6 mice) 1 on LID. In this study, the C57BL/6 mice received a unilateral lesion with 6-OHDA $(12 \mu \mathrm{g})$. After that, they received L-DOPA $(25 \mathrm{mg} / \mathrm{kg})$ plus Benserazide $(12.5 \mathrm{mg} / \mathrm{kg})$ daily, i.p.. Simultaneously, these animals performed exercises in a running wheel (voluntary activity) for 14 days. After the protocol training, there was no modification of the lesion caused by 6OHDA (Figure 3 A-B). However, physical exercise decreased the axial and limb dyskinesia without orofacial

Table 1 - Characteristics of the original articles, selected in the bibliographic search, address the theme of LID and physical activity or exercise from 2012 to 2018 .

\begin{tabular}{|c|c|c|c|}
\hline References & $\begin{array}{l}\text { Number of participants } \\
\text { or animals and age }\end{array}$ & Intervention & Outcomes \\
\hline 31 & $\begin{array}{l}\mathrm{N}=40 \\
\text { Age: } 71 \pm 8 \text { y.o. }\end{array}$ & $\begin{array}{l}\text { Intensive exercise ( } 60 \text { hours } / 4 \text { weeks) x non-intensive } \\
\text { ( } 30 \text { hours } / 4 \text { weeks involving physiotherapy only) }\end{array}$ & $\begin{array}{l}\text { The intensive exercise presented better results in } \\
\text { UPDRS scale and dyskinesias score (reduce } 71 \% \text { ) }\end{array}$ \\
\hline 32 & $\begin{array}{l}\mathrm{N}=40 \\
\text { Age: } 70 \pm 8 \text { y.o. }\end{array}$ & $\begin{array}{l}\text { Intensive ( } 60 \text { hours } / 4 \text { weeks) exercises. assessment at } \\
\text { baseline, at the end, and 6-month follow-up }\end{array}$ & Reduction in drug dosage and adverse effects \\
\hline 33 & $\begin{array}{l}\mathrm{N}=59 \\
\text { C57BL/6 mice Age: } 8-10 \\
\text { weeks old }\end{array}$ & $\begin{array}{l}\text { L-DOPA/benserazide model }(25 / 12.5 \mathrm{mg} / \mathrm{kg} \text {, i.p. }) \text { - } \\
\text { Running wheel and sedentary groups for } 2 \text { weeks }\end{array}$ & $\begin{array}{l}\text { Exercise prevented LID and normalization of stria- } \\
\text { topallidal dopaminergic signaling }\end{array}$ \\
\hline 39 & $\begin{array}{l}\mathrm{N}=62 \\
\text { Swiss albino mice Age: }(8- \\
10 \text { weeks old) }\end{array}$ & $\begin{array}{l}\text { L-DOPA/benserazide model }(50 / 25 \mathrm{mg} / \mathrm{kg} \text {, i.p.). Tread- } \\
\text { mill-controlled exercise or sedentary groups for } 4 \text { weeks }\end{array}$ & $\begin{array}{l}\text { Exercise attenuates LID and increases the striatal } \\
\text { immunocontent of GDNF }\end{array}$ \\
\hline
\end{tabular}

GDNF: cell-derived neurotrophic factor; LID: L-DOPA-induced dyskinesia; i.p: intraperitoneal; y.o.: Years old. 



Figure 2 - Graphical representation of time-treatment interaction for the variable AIMS. Differences in the rehabilitation treatment (intensive and nonintensive) effect are reflected by those in the line's slope joining the mean value AIMS at baseline and after rehabilitation in the two groups (A). Patients undergoing the IRT protocol may decrease the levodopa dose after the rehabilitation protocol (B). AIMS, abnormal involuntary movement scale; IRT, intensive rehabilitation treatment; NIRT, nonintensive rehabilitation treatment.

dyskinesia (Figure $3 \mathrm{C}$ ). These effects of voluntary exercise were associated with the normalization of dopaminergic signaling in the striatum. More specifically, an increase in hyperphosphorylation of DARPP-32, CDK5, and expression of c-Fos (Figure 3 D-G).

Finally, exercise can increase the glial cell-derived neurotrophic factor (GDNF), related to dyskinesia control. Treadmill protocol for four weeks (30 minutes) showed an antidyskinetic effect in the Swiss mice model. An increase in striatal GDNF levels provides a new mechanistic view (Figure 4). The GDNF emerges as a particularly promising candidate since it exerts an essential role in the development and maintenance of spinal motor neurons and midbrain dopaminergic neurons. Moreover, GDNF downregulation is associated with PD pathophysiology. Additionally, Cohen ${ }^{34}$ demonstrated that limb exercise could prevent behavioral deficits and neurochemicals induced by the administration of 6-OHDA; they related this beneficial effect of the physical exercise to increased levels of the GDNF in the striatal area. Evidence from both in vivo and in vitro studies indicates the protective and regenerative potential of GDNF on dopaminergic neurons $^{35}$.

Interestingly, intrastriatal pretreatment (6-OHDA injury) with GDNF $(100 \mu \mathrm{g})$ in rats prevents the degeneration of dopaminergic neurons ${ }^{36}$. Besides, intracerebroventricular GDNF in the 6-OHDA animal model restores striatal $\mathrm{TH}$ levels and improves motor symptoms $^{37}$. Additionally, intrastriatal GDNF injection $(5 \mu \mathrm{g})$ reduced LID in MPTP-treated monkeys ${ }^{38}$. Collectively, these results indicate that the increased striatal GDNF of dyskinetic animals might represent a critical attenuating effect mechanism of treadmill exercise in LID $^{39}$. Thus, convergent evidence from clinical and experimental studies suggest that physical exercise might act as a modifying agent and could have antidyskinetic effects.
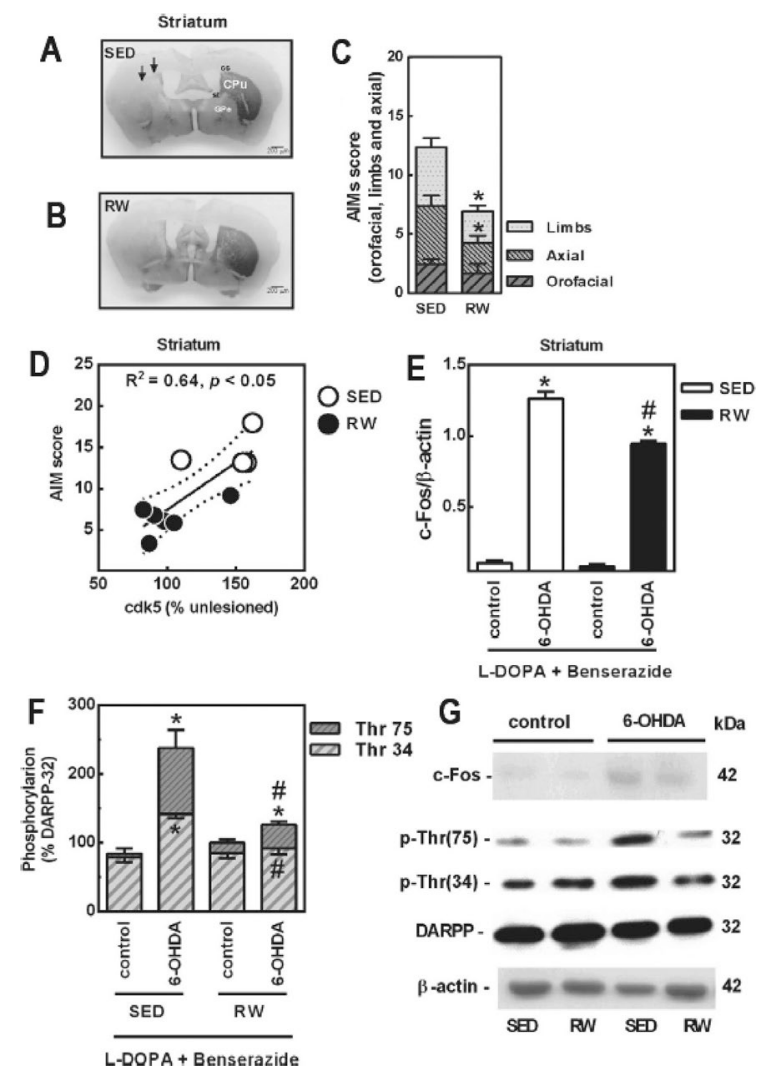

Figure 3 - Exercise and L-DOPA/Benserazide $(25 / 12.5 \mathrm{mg} / \mathrm{kg}$, i.p.) revealed no effect on neurodegeneration, evaluated as a decreased immunoreactivity of tyrosine hydroxylase in the lesioned striatum (A, B); however, exercise was effective in reducing AIM (C). L-DOPA-induced dyskinesia's severity correlated with increased striatal levels of cdk5 (D) and c-Fos (E). L-DOPA also triggered hyperphosphorylation of DARPP32 at $\operatorname{Thr}(34)$ and $\operatorname{Thr}(75)$ sites in sedentary mice (F). Notably, exercise (RW) decreased these neurochemical changes typically associated with L-DOPA-induced dyskinesia. AIM, abnormal involuntary movements; cdk5, CPu, Caudate-putamen; GPe, external globus pallidus; cyclindependent kinase 5; DARPP-32, dopamine and cAMP-regulated phosphoprotein $32 \mathrm{kDa}$; RW, running wheel; SED, sedentary; st, striatum terminals; Thr, threonine residue; 6-OHDA, 6-hydroxydopamine. 


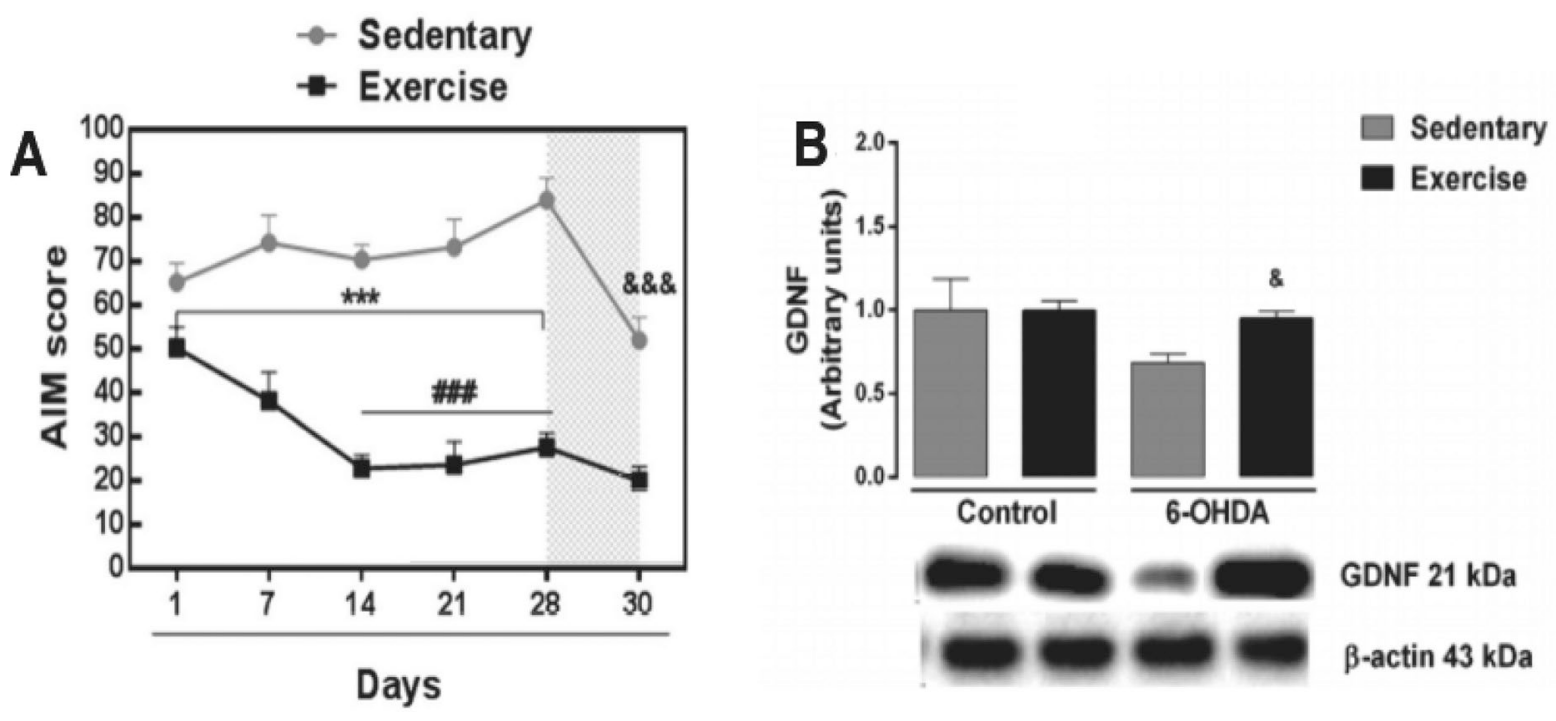

Figure 4 - Exercise (treadmill) or sedentary groups were treated with L-DOPA/Benserazide (50/25 mg/kg, i.p.) for 4 weeks. Exercised mice presented a reduced AIM score from 14th, 21th, and 28th days of treatment $(* * * P<0.001$ vs. sedentary; \#\#\# $<0.001$ vs. exercised on the first day (A). Exercise increased the GDNF immunocontent in the 6-OHDA lesioned striatum of dyskinetic mice (B). AIM, abnormal involuntary movements; GDNF, cellderived neurotrophic factor; 6-OHDA, 6-hydroxydopamine.

\section{Tardive dyskinesia and exercise}

The continuous use of antipsychotic drugs can cause tardive dyskinesia (TD), initially observed in the 1950s. These patients showed movements that were acute and short-lived in some cases and chronic in others ${ }^{40}$. The term "tardive dyskinesia" was introduced by Faurbye in $1964^{41}$, highlighting the delayed onset of the condition $^{42,43}$. These movements also occur after the antipsychotic discontinuation or its dosage reduction. The pathophysiology of TD include upregulation of D2 and D3 receptors, deregulated DA influence on the substantia nigra, striatal neurodegeneration, changes in synaptic plasticity due to surges of $\gamma$-aminobutyric acid in the striatal neurons responsible for motor coordination, oxidative trauma, and changes in 5-HT2 receptor signaling ${ }^{44-47}$. The D2 receptor blockade causes an increase in D2 receptor synthesis (upregulation), creating a receptor supersensitivity.

The pattern ("topography") of dyskinesia is essential for differentiating the functional impact of this disease. Truncal TD, for example, affects gait and posture and exerts its detrimental effect quite broadly by interfering with their ADLs that require standing or moving, such as grooming, dressing, toileting, bathing, ambulating, and transport. In contrast, orofacial TD would not have a significant impact on these tasks but would perhaps affect speech, which is required for effective interpersonal interactions or getting and keeping a job ${ }^{48}$. Orofacial dyskinesia is more frequently type founded in animal models induced by reserpine.

It is important to emphasize that people with persistent mental illness have reduced physical activity and may interfere with their $\mathrm{ADLs}^{49}$. Several forms of TD were described, including tardive stereotypy, tardive dystonia, and tardive akathisia ${ }^{50}$. Occasionally, chorea (unlike LID), myoclonus, and tremor can also be a part of the TD spectrum $^{51}$. Although several patients might not be aware of their TD, it can cause complications, including respiratory distress, dysphagia, dysarthria, falling, and suicide ${ }^{51,52}$.

These patients have gait speed problems like cadence, step length, posture, arm swing, gait initiation, turning, and gait efficiency. The loss of lower extremity power/strength or lack of endurance may further worsen the performance of gait-related everyday activities ${ }^{52-54}$. The gait can help with motor performance under a cognitive load, using dual-task gait assessments (e.g., walking while performing an attention-demanding task $)^{55,56}$. They are also at high risk of major fall-related injuries such as fractures and head injuries that increase the mortality risk. Dual-task interventions improve attention and executive function as well as memory in older adults without dementia. Verghese et al. ${ }^{57}$ conducted a pilot study in 24 older adults randomly assigned, 10 participants who completed the cognitive remediation presented improvement in the gait velocity during normal walking and walking while talking (dual-task).

Few studies refer to the effects of exercise in patients with TD; a summary of these articles is in Table 2. A 25year-old woman with severe TD due to neuroleptics had improved movement while skateboarding after deep brain stimulation (DBS). The participant received pale DBS, and gait and inline skates, the data were assessed before and after DBS; her twin sister was the control counterpart. The authors conclude that the possible explanation for her improvement include the balance stability required by 
Table 2 - Characteristics of the original articles, selected in the bibliographic search, address the theme of TD and physical activity or exercise from 1994 to 2017.

\begin{tabular}{|c|c|c|c|}
\hline References & $\begin{array}{l}\text { Number of participants } \\
\text { or animals and age }\end{array}$ & Intervention & Outcomes \\
\hline 3 & $\begin{array}{l}\mathrm{N}=10 \\
\text { age: } 38.1 \pm 12.8 \mathrm{y} / \mathrm{o}\end{array}$ & A cycle ergometer exercise test & $\begin{array}{l}\text { The patients had a normal response to progressive exer- } \\
\text { cise and inspiratory time }\end{array}$ \\
\hline 58 & $\begin{array}{l}\mathrm{N}=1 \\
\text { Age: } 25-\mathrm{y} / \mathrm{o} \text { woman }\end{array}$ & Inline skating assessed before and after DBS & $\begin{array}{l}\text { Substantial improvement of movements while inline } \\
\text { skating }\end{array}$ \\
\hline 55 & $\begin{array}{l}\mathrm{N}=20 \\
\text { Age: } 82 \pm 7.5 \mathrm{y} / \mathrm{o}\end{array}$ & $\begin{array}{l}\text { Dual-task- low-intensity exercise, } 24 \text { sessions ( } 12 \\
\text { weeks, } 1 \mathrm{~h} / 2 \mathrm{x} \text { week) }\end{array}$ & $\begin{array}{l}\text { Improved gait velocity and cadence, stride length, and } \\
\text { single support }\end{array}$ \\
\hline 65 & $\begin{array}{l}\mathrm{N}=30 \\
\text { male Wistar rats Age: } 3 \\
\text { months old }\end{array}$ & $\begin{array}{l}\text { Reserpine model ( } 1 \text { or } 5 \mathrm{mg} / \mathrm{kg} \text { ) RW or treadmill } \\
\text { exercise ( } 20-25 \mathrm{~min} / \text { day) } 5 \text { days/week, } 4 \text { weeks }\end{array}$ & $\begin{array}{l}\text { Reserpine rats presented short-term social memory defi- } \\
\text { cits that were selectively improved by the exercise train- } \\
\text { ing }\end{array}$ \\
\hline 66 & $\begin{array}{l}\mathrm{N}=32 \\
\text { male Wistar rats Age: } 3 \\
\text { months old }\end{array}$ & $\begin{array}{l}\text { Reserpine model }(1 \mathrm{mg} / \mathrm{kg} \text {-sc), swimming sessions } \\
\text { ( } 1 \mathrm{~h} / \text { day, for eleven weeks) }\end{array}$ & Intense physical exercise increases orofacial dyskinesia \\
\hline 67 & $\begin{array}{l}\mathrm{N}=24 \\
\text { male Wistar rats Age: } 3 \\
\text { months old }\end{array}$ & $\begin{array}{l}\text { Reserpine model }(1 \mathrm{mg} / \mathrm{kg} \text {-sc swimming }(5 \mathrm{x} \text { week } \\
-8 \text { weeks }) \text { - increased } 15 \mathrm{~min} / \text { day until } 90 \mathrm{~min} / \text { day }\end{array}$ & $\begin{array}{l}\text { Vacuous chewing and facial twitching partially pre- } \\
\text { vented by exercise }\end{array}$ \\
\hline
\end{tabular}

RW: Running well.

inline skating provides external cues that are less prominent during gait. Since TD has a variable response to treatments, the proposal of current research that minimizes TD and that could advance the treatment and rehabilitation in this disabling disorder ${ }^{58}$.

One of the complications related to TD is the limitations of physical capacity. Several studies reported a modest but significant weight loss or improved cardiovascular fitness among patients with schizophrenia. Patients with schizophrenia are two- to three-times more likely to have a higher mortality rate and a reduced lifespan expectancy, approximately 13-30 years ${ }^{59-61}$. The treatment with antipsychotics, particularly the second generation, largely contributes to metabolic complications. Studies implemented interventions such as physical activity, dietary modification, or psychoeducation that targeted metabolic physical health and physical fitness. Some programs that implemented walking as the primary intervention presented significant changes in the tested parameters, mainly improvement in cardiovascular fitness and weight loss ${ }^{62-64}$.

Patients with TD can also develop respiratory dysrhythmias (RDs). These include irregular respiratory rate and rhythm in association with involuntary grunts and gasping sounds ${ }^{3}$. The cycle ergometer exercise test in the patient's symptom-limited maximal workload. The modified V2 and arterial oxygen saturation were monitored continuously with a portable oximeter. In this study, they compared patients with healthy control subjects. Exertional dyspnea is a common presenting symptom of patients with RDs. The authors suggest that RDs are not the cause of premature termination of exercise in patients with TD. Both volume and breathing frequency increased in a regular curvilinear pattern, and no patient demonstrated significant arterial oxygen desaturation during exercise $^{3}$.
In animal models of TD, moderate physical exercise plays an essential role in improving the motor and cognitive impairments associated with monoaminergic depletion. The exercise training in the reserpine model $(5.0 \mathrm{mg} / \mathrm{kg}$, s.c.) for four weeks in the running wheel or treadmill attenuated the motor problems ${ }^{65}$. In the reserpine animal model, swimming activity, for eleven weeks, provoked an increase in orofacial dyskinesia ${ }^{66}$. However, swimming protocol for five times per week (increased $15 \mathrm{~min}$ per day until swam $90 \mathrm{~min} /$ day), for eight weeks showed prevention in orofacial dyskinesia ${ }^{67}$.

\section{Paroxysmal dyskinesias and exercise}

In 1740, Mount and Reback introduced the term "familial paroxysmal choreoathetosis. They described a 23-year-old man with an autosomal dominant disorder manifested by attacks choreoathetosis involving arms and legs ${ }^{68}$. The attacks occurred twice or three times a day for $5 \mathrm{~min}$ to several hours precipitated by alcohol, coffee, tea, fatigue, and smoking. Numerous reports of the patients with episodic dyskinesia have followed, and several classifications have been proposed to categorize this movement disorder ${ }^{69}$. In 1977, Lance reviewed 100 cases and added 12 patients with "familial paroxysmal dystonic choreoathetosis" "69. The author classified the cases, primarily according to the duration, as (1) paroxysmal dystonic (prolonged attacks lasting from 2 min to $4 \mathrm{~h}$ ), (2) paroxysmal kinesigenic choreoathetosis (brief attacks lasting from few seconds to $5 \mathrm{~min}$ and induced by sudden voluntary movement), and (3) intermediate form (attacks lasting from 5-30 min and caused by continued exertion). Paroxysmal dyskinesias (PxDs) is a transient abnormal, involuntary movement, such as choreoathetosis and dystonia. PxDs are not involved in tonic- 
clonic seizures and are not associated with epileptiform discharges or alterations in consciousness ${ }^{70}$. PxDs is subdivided into four subgroups based on their precipitating factors: paroxysmal kinesigenic dyskinesia (PKD), paroxysmal non-kinesigenic dyskinesia (PNKD), paroxysmal exercise-induced dyskinesia (PED), and paroxysmal hypnogenic dyskinesia (PHD). The association between PxDs and other neurological disorders, such as epilepsy or ataxia occasionally observed within one individual or family.

Mutations in SLC2A1 are the main cause of PED, which can be isolated or be a part of a more complex phenotype ${ }^{18,71,72}$. Mutations in GCH1, PARK2 (encoding Parkin), or other genes involved in recessive juvenile PD can occasionally cause $\mathrm{PED}^{73}$. Rare genetic causes include modifications in PRRT2 ${ }^{74}, \mathrm{ATP} 1 \mathrm{~A} 3^{75}, \mathrm{ADCY}^{76}$, PDHA1, and PDHX (pyruvate dehydrogenase deficiency $)^{76}$. Symptomatic treatment with antiepileptics, levodopa, or acetazolamide can be useful ${ }^{15}$.

Interestingly, in contrast to LID, only physical activities such as domestic activities in patients with PED can activate dyskinesias, a rarer and less welldocumented group. Many studies of genetic studies have been carried out to understand the pathophysiol- ogy of the attacks. In summary, the attacks are triggered by prolonged exercise like walking or running characterized by attacks of dystonia and chorea, typically lasting for $5-30 \mathrm{~min}^{14}$. The attacks often start in the body part involved in the activity and last for 1015 min after stopping the exercise. PED made walking impossible and caused falls in some of the patients. Some patients were able to stand despite the PED, or walk with difficulty, but most patients had to sit down until the movements subsided. A summary of the studies is shown in Table 3.

The co-occurrence of PED and epilepsy is frequently. The frequency of attacks is variable, depending on the routine level of physical exercise. These attacks may be accompanied by migraine without aura ${ }^{77}$ or a combination of alternating hemiplegia, epilepsy, and ataxia ${ }^{78}$. Epilepsy and writer's cramp combination was reported is these patients ${ }^{79}$. In some patients, PED presenting signs of young-onset idiopathic PD due to the Parkin gene ${ }^{80}$. PED and epilepsy are associated with a low glucose concentration in the presence of normoglycaemia. Although several family members reported that glucose and sugar alleviated symptoms, carbohydrate-rich diets are unsuccessful.

Table 3 - Characteristics of the original articles, selected in the bibliographic search, are PED and physical activity or exercise, from 1978 to 2012.

\begin{tabular}{|c|c|c|c|}
\hline References & $\begin{array}{l}\text { Number of participants or } \\
\text { animal and age }\end{array}$ & PED episodes & Intervention \\
\hline 82 & $\begin{array}{l}\mathrm{N}=14 \\
\text { Age: } \pm 7.1 \mathrm{y} / \mathrm{o} \text { age at onset }\end{array}$ & $\begin{array}{l}\text { Long periods of exercise associated with } \\
\text { migraine, hemiplegia, ataxia, and epilepsy }\end{array}$ & $\begin{array}{l}\text { Ion channel dysfunction may, therefore, constitute the link } \\
\text { for PED and epilepsy }\end{array}$ \\
\hline 17 & $\begin{array}{l}\mathrm{N}=7 \\
\text { Age: } 16 \text { and a } 24-\mathrm{y} / \mathrm{o}, \mathrm{man}\end{array}$ & $\begin{array}{l}\text { During bursts of exercise. Dystonia by sud- } \\
\text { den movements, hand, arm, and leg }\end{array}$ & $\begin{array}{l}\text { Great response to anticonvulsants resulting in a decrease in } \\
\text { the frequency or amelioration of the paroxysms }\end{array}$ \\
\hline 18 & $\begin{array}{l}\mathrm{N}=1 \\
\text { Age: } 26 \text { y/o, woman }\end{array}$ & $\begin{array}{l}\text { Started in } 13 \text { years old, fatigued after pro- } \\
\text { longed walking }\end{array}$ & $\begin{array}{l}\text { Episodes were increasing when removed carbamazepine or } \\
\text { when she had not eaten for an extended period }\end{array}$ \\
\hline 69 & $\begin{array}{l}\mathrm{N}=2 \\
\text { Age: } 58 \text { and } 23-\mathrm{y} / \mathrm{o} \text { man; } \\
-44-\mathrm{y} .0 . \text {, woman }\end{array}$ & Walking long distances -5 to 30 minutes & $\begin{array}{l}\text { Precipitating factor was sudden movement after rest, excite- } \\
\text { ment, stress, and hyperventilation }\end{array}$ \\
\hline 71 & $\begin{array}{l}\mathrm{N}=15 \\
\text { Age: } 15 \mathrm{y} / \mathrm{o}\end{array}$ & $\begin{array}{l}\text { Prolonged exercise (attacks } 5 \text { minutes to } 2 \\
\text { hours) several times weekly }\end{array}$ & $\begin{array}{l}\text { The attack was not modified by trials of phenytoin, valproate, } \\
\text { acetazolamide, or clonazepam }\end{array}$ \\
\hline 83 & $\begin{array}{l}\mathrm{N}=1 \\
\text { Age: } 7-\mathrm{y} / \mathrm{o}\end{array}$ & $\begin{array}{l}\text { Walking ( } 20 \text { minutes) or running during (5-30 } \\
\text { minutes) }\end{array}$ & $\begin{array}{l}\text { Loss of function mutations had more severe cognitive and } \\
\text { motor impairment. They ceased after stopping exercise }\end{array}$ \\
\hline 73 & $\begin{array}{l}\mathrm{N}=3 \\
\text { Age: } 40 \text { and } 8 \mathrm{y} / \mathrm{o} ; 41 \mathrm{y} / \mathrm{o} \\
\text { woman }\end{array}$ & $\begin{array}{l}\text { Young-onset Parkinsonisn; attacks after pro- } \\
\text { longed exercise (walking, running, or swim- } \\
\text { ming) }\end{array}$ & $\begin{array}{l}\text { Carbamazepine for } 2 \text { months produced no benefit- treatment, } \\
\text { and L-Dopa stopped the events }\end{array}$ \\
\hline 74 & $\begin{array}{l}\mathrm{N}=2 \\
\text { Age: } 8 \text { e } 10-\mathrm{y} / \mathrm{o}\end{array}$ & $\begin{array}{l}\text { Fatigue or exercise after a few seconds - short } \\
\text { duration of attacks lasting }\end{array}$ & $\begin{array}{l}\text { Response to antiepileptic drugs varied in both families. } \\
\text { Remission seemed to be around } 20 \text { years. }\end{array}$ \\
\hline 75 & $\begin{array}{l}\mathrm{N}=4 \\
\text { Age: } 51 \text { and } 23 \text { y/o man; } 26 \\
\text { and } 3 \text { y.o. woman }\end{array}$ & $\begin{array}{l}\text { Exercise-induced dystonia in the absence of } \\
\text { plegic attacks }\end{array}$ & The ATP1A3 and environmental factors were determinants \\
\hline 77 & $\begin{array}{l}\mathrm{N}=14 \\
\text { Age: Mean of onset } 12 \mathrm{y} / \mathrm{o} \\
\text { man to woman: ratio } 3: 1\end{array}$ & $\begin{array}{l}\text { Attacks dystonic ( } 15 \text { and } 30 \text { minutes). - pre- } \\
\text { cipitated by walking or another type of the } \\
\text { exercise }\end{array}$ & $\begin{array}{l}\text { Treatment with acetazolamide did not prevent the attacks of } \\
\text { PED. Treatment with sodium valproate resulted in some } \\
\text { improvement }\end{array}$ \\
\hline
\end{tabular}


Table 3 - continued

\begin{tabular}{|c|c|c|c|}
\hline References & $\begin{array}{l}\text { Number of participants or } \\
\text { animal and age }\end{array}$ & PED episodes & Intervention \\
\hline 78 & $\begin{array}{l}\mathrm{N}=1 \\
\text { Age: } 20 \text { y/o woman }\end{array}$ & Occurred after 10-20 minutes walking & $\begin{array}{l}\text { Prednisolone improved ataxia and cessation of both seizures } \\
\text { and PED }\end{array}$ \\
\hline 79 & $\begin{array}{l}\mathrm{N}=2 \\
\text { Age: } 23 \text { y/o man } 11 \text { y.o girl }\end{array}$ & $\begin{array}{l}\text { Prolonged physical exercise, mainly ( } 20 \mathrm{~min}- \\
\text { utes walk) }\end{array}$ & After clonazepam, the attacks stopped \\
\hline 80 & $\begin{array}{l}\mathrm{N}=2 \\
\text { Age: } 27 \text { and } 45 \mathrm{y} / \mathrm{o} \text { man }\end{array}$ & $\begin{array}{l}\text { Prolonged or minimal exercises, unilateral } \\
\text { and affecting the foot in both patients }\end{array}$ & $\begin{array}{l}\text { Excessive dopamine release could lead to relative dopamine } \\
\text { deficiency, leading to dystonia }\end{array}$ \\
\hline 72 & $\begin{array}{l}\mathrm{N}=20 \\
\text { Age: } 6 \text { months old }\end{array}$ & Mouse mutants, tottering and lethargic mice & $\begin{array}{l}\text { A peak characterized attacks at } 40 \text { to } 60 \text { minutes, returning to } \\
\text { the baseline after } 90 \text { to } 120 \text { minutes. }\end{array}$ \\
\hline 81 & $\begin{array}{l}\mathrm{N}=36 \\
\text { Age: } 16 \text { weeks old }\end{array}$ & $\begin{array}{l}\text { Lethargic mutant mice Treadmill and motor } \\
\text { behavioral until the onset of dyskinesias }\end{array}$ & $\begin{array}{l}\text { Attacks promoted by motor activity, after very brief motor } \\
\text { activity, few minutes, many times per hour }\end{array}$ \\
\hline
\end{tabular}

PD: Parkinson Disease; PED: paroxysmal exercise-induced dyskinesia; y.o.: Years old.

Although some pharmacological treatments with anticonvulsants had no effect on some patients, others the anticonvulsants, such as carbamazepine ${ }^{18,73}$, clonaze$\operatorname{pan}^{79}$, and sodium valproate, decrease the occurrence of attacks ${ }^{77}$. A previos study has shown that 15 patients had no effet with any anticonvulsants. One case was reported improvement with the use of the steroidal anti-inflammatory drug (Prednisolone) in a 20-year-old woman. However, studies show that the cessation of attacks occurs spontaneously after a few years. Interestingly, in experimental models, using mouse mutants, tottering and lethargic mice, have shown the same pattern of response. Two studies show that after evaluation with short motor tests and after physical exercise on a treadmill or motor task for a brief moment, animals present dyskinetic attacks for minutes and sometimes for hours ${ }^{72,81}$.

\section{Conclusions}

In our mini-review, we show that exercise improves LID and motor impairments of PD patients and PD animal models. This decrease in LID is likely as consequence of dopaminergic normalization and an increase of neurotrophic factors. Although this type of intervention has a beneficial effects on patients with TD, few studies are available because some patients have mental problems making diificult the approach with physical exercise and/ or physical activity. Eventually, PED is an entirely different pattern from the other dyskinesias and physical exercise. This condition can worsen the symptoms after physical activity performance. A schematic conclusion is shown in Figure 5.

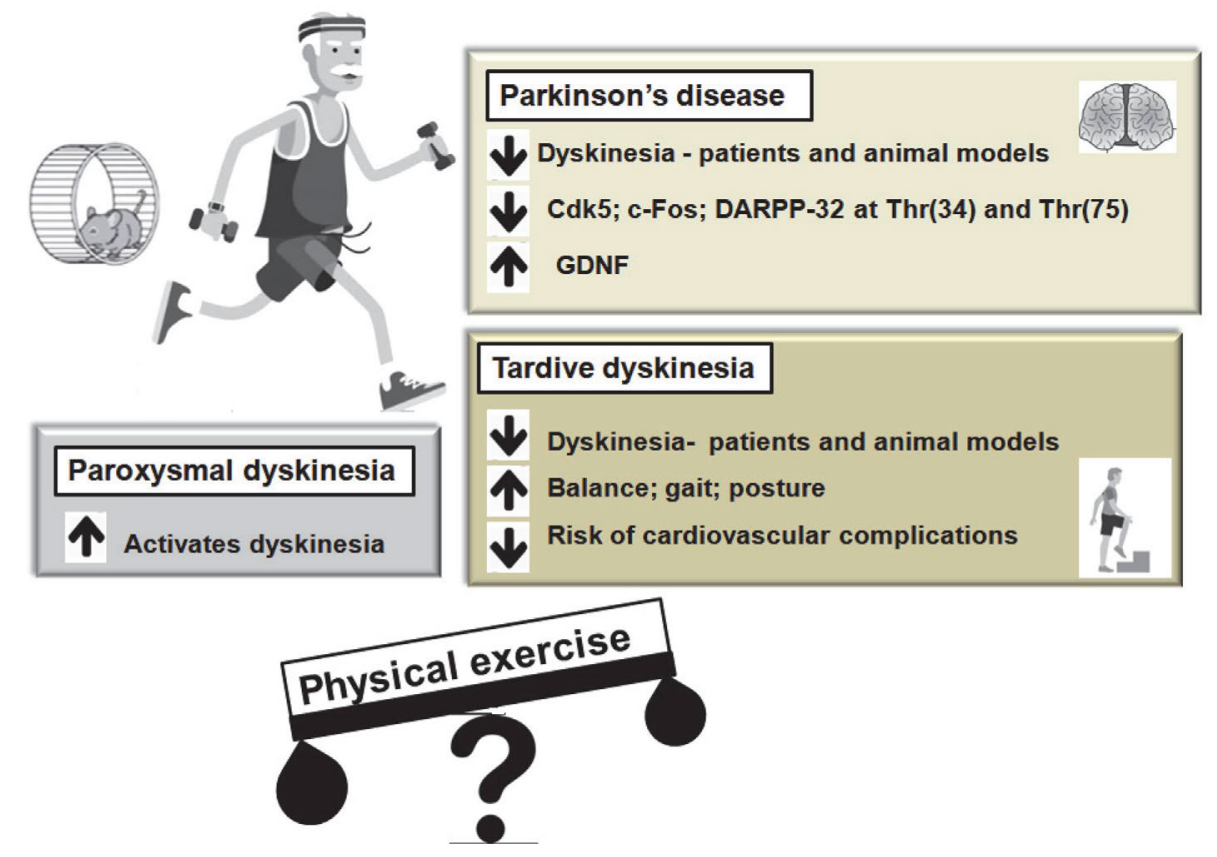

Figure 5 - Schematic drawing: Exercise has beneficial motor effects on dyskinesias in animal models and patients with Parkinson's disease or tardive dyskinesia. However, exercise can activate PED. 


\section{Acknowledgments}

This study was financed by the Coordenação de Aperfeiçoamento de Pessoal de Nível Superior-Brasil (CAPES)Finance Code 1. The manuscript received financial support from Conselho Nacional de Desenvolvimento Científico e Tecnológico (CNPq) and Fundação de Amparo à Pesquisa e Inovação do Estado de Santa Catarina (FAPESC). A.S.A. Jr. was a CNPq fellowship.

\section{References}

1. Fahn S. The spectrum of levodopa-induced dyskinesias. Ann Neurol. 2000;47(7):2-9.

2. Del-Bel E, Padovan-Neto FE, Bortolonza M, Tumas V, Aguiar Jr, S, Raisman-Vorzari R, Prediger RD. Nitric oxide, a new player in L-DOPA-induced dyskinesia? Front Biosci. 2015;(7):168-92.

3. Wilcox PG, Bassett A, Jones B, Fleetham, JA. Respiratory dysrhythmias in patients with tardive dyskinesia. Chest. 1994;(105):203-7.

4. Yassa R, Lal S. Respiratory irregularity and tardive dyskinesia. A prevalence study. Acta Psychiatr Scand. 1986; (73):506-10.

5. Rascol O, Fabre, N. Dyskinesia: L-dopa-induced and tardive dyskinesia. Clin Neuropharmacol. 2001;(24):313-23.

6. Hornykiewicz O. The mechanisms of action of L-dopa in Parkinson's disease. Life Sci. 1974;(15):1249-59.

7. Hornykiewicz O. A brief history of levodopa. J Neurol. 2010;257,S249-52.

8. Thanvi B, Lo N, Robinson T. Levodopa-induced dyskinesia in Parkinson's disease: clinical features, pathogenesis, prevention and treatment. Postgrad Med. 2007;(83):384-8.

9. Rascol O. Drugs and drug delivery in PD: optimizing control of symptoms with pramipexole prolonged-release. Eur J Neurol. 2011;(18):3-10.

10. Haro J M, Salvador-Carulla L. The SOHO (Schizophrenia Outpatient Health Outcome) study: implications for the treatment of schizophrenia. CNS Drugs. 2006;(20):293-301.

11. Lerner V, Miodownik C. Motor symptoms of schizophrenia: is tardive dyskinesia a symptom or side effect? A modern treatment. Curr Psychiatry Rep. 2011;(13):295-304.

12. Merrill R M, Lyon JL, Matiaco PM. Tardive and spontaneous dyskinesia incidence in the general population. BMC Psychiatry. 2013;(13):152.

13. Gardiner AR, Jaffer F, Dale RC, Labrun R, Erro R, Meyer $\mathrm{E}$, et al. The clinical and genetic heterogeneity of paroxysmal dyskinesias. Brain. 2015:(138):3567-80.

14. Meneret A, Roze E. Paroxysmal movement disorders: An update. Rev Neurol. (Paris). 2016;(172):433-45.

15. Bhatia, K P. Paroxysmal dyskinesias. Mov Disord. 2011: (26):1157-65.

16. Demirkiran M, Jankovic J. Paroxysmal dyskinesias: clinical features and classification. Ann Neurol. 1995;(38):571-9.

17. Goodenough DJ, Fariello RG, Annis BL, Chun RW. Familial and acquired paroxysmal dyskinesias. A proposed classification with delineation of clinical features. Arch Neurol. 1978;(35):827-31.
18. Bovi T, Fasano A, Juergenson I, Gellera C, Castellotti B, Fontana E, et al. Paroxysmal exercise-induced dyskinesia with self-limiting partial epilepsy: a novel GLUT-1 mutation with benign phenotype. Parkinsonism Relat Disord. 2011;(17):479-81.

19. Calne DB. Treatment of Parkinson's disease. N Engl J Med. 1993;(329):1021-7.

20. Horstink M, Tolosa E, Bonuccelli U, Deuschl G, Friedman A, Kanovsky $P$, et al. Review of the therapeutic management of Parkinson's disease. Report of a joint task force of the European Federation of Neurological Societies and the Movement Disorder Society-European Section. Part I: early (uncomplicated) Parkinson's disease. Eur J Neurol. 2006; (13)1170-85.

21. Kieburtz, K. Issues in neuroprotection clinical trials in Parkinson's disease. Neurology. 2006;(66):S50-7.

22. Seppi K, Weintraub B, Coelho M, Perez-Lloret S, Fox SH, Katzenschlager R, Hametner EM, et al. The Movement Disorder Society Evidence-Based Medicine Review Update: Treatments for the non-motor symptoms of Parkinson's disease. Mov Disord. 2011;(26):S42-80.

23. Jenner P. Molecular mechanisms of L-DOPA-induced dyskinesia. Nat Rev Neurosci. 2008;(9):665-77.

24. Kaminer J, Thakur P, Evinger C. Effects of subthalamic deep brain stimulation on blink abnormalities of 6-OHDA lesioned rats. J Neurophysiol. 2015;(113):3038-46.

25. Wang L, Li J, Chen J. Levodopa-Carbidopa Intestinal Gel in Parkinson's Disease: A Systematic Review and Meta-Analysis. Front Neurol. 2018:(9):620.

26. Standaert DG, Rodrigez RL, Slevin, JT, Lobatz M, Eaton S, Chatamra $\mathrm{K}$, et al. Effect of Levodopa-carbidopa Intestinal Gel on Non-motor Symptoms in Patients with Advanced Parkinson's Disease. Mov Disord Clin Pract. 2017;(4):82937.

27. Archer T, Fredriksson A. Physical exercise attenuates MPTPinduced deficits in mice. Neurotox Res. 2010;(18):313-27.

28. Fredriksson A, Stigsdotter I M, Hurtig A, Ewalds-Kvist B, Archer T. Running wheel activity restores MPTP-induced functional deficits. J Neural Transm. 2011;(118):407-20.

29. Fisher BE, Petzinger GM, Nixon K, Hogg E, Bremmer S, Meshul CK, et al. Exercise-induced behavioral recovery and neuroplasticity in the 1-methyl-4-phenyl-1,2,3,6-tetrahydropyridine-lesioned mouse basal ganglia. J Neurosci Res. 2004;(77):378-90.

30. Vuckovic MG, Li Q, Fisher B, Nacca A, Leahy RM, Walsh JP, Mukherjee, et al. Exercise elevates dopamine D2 receptor in a mouse model of Parkinson's disease: in vivo imaging with [(1)(8)F]fallypride. Mov Disord. 2010;(25):277784.

31. Frazzitta G, Bertotti G, Morelli M, Riboldazzi G, Pelosin $\mathrm{PB}$, Boveri N, et al. Rehabilitation improves dyskinesias in Parkinsonian patients: A pilot study comparing two different rehabilitative treatments. NeuroRehabilitation. 2012; (30):295-301.

32. Frazzitta G, Morelli M, Bertotti G, Felicetti G, Pezzoli G, Maestri R. Intensive rehabilitation treatment in parkinsonian patients with dyskinesias: A preliminary study with 6month follow-up. Parkinson's Dis. 2012;(2012):4-7.

33. Aguiar AS, Moreira ELG, Hoeller AA, Oliveira PA, Córdova FM, Glaser V, et al. Exercise attenuates levodopa- 
induced dyskinesia in 6-hydroxydopamine-lesioned mice. Neuroscience. 2013;(243):46-53.

34. Cohen AD, Tillerson JL, Smith AD, Schallert T, Zigmond MJ. Neuroprotective effects of prior limb use in 6-hydroxydopamine-t. Neuroanat. 2015; (9): 10.reated rats: possible role of GDNF. J Neurochem. 2003;(85):299-305.

35. d'Anglemont de Tassigny X, Pascual A, Lopez-Barneo J. GDNF-based therapies, GDNF-producing interneurons, and trophic support of the dopaminergic nigrostriatal pathway. Implications for Parkinson's disease. Front Neuroanat. 2015;(9):10.

36. Aoi M, Date I, Tomita S, Ohmoto T. The effect of intrastriatal single injection of GDNF on the nigrostriatal dopaminergic system in hemiparkinsonian rats: behavioral and histological studies using two different dosages. Neurosci Res. 2000;(36):319-25.

37. Kirik D, Georgievska B, Rosenblad C, Bjorklund A. Delayed infusion of GDNF promotes recovery of motor function in the partial lesion model of Parkinson's disease. Eur J Neurosci. 2011;(13):1589-99.

38. Iravani MM, Costa S, Jackson MJ, Tel BC, Cannizzaro C, Pearce RK, et al. GDNF reverses priming for dyskinesia in MPTP-treated, L-DOPA-primed common marmosets. Eur J Neurosci. 2001(13):597-608.

39. Speck AE, Schamne MG, Aguiar Jr, AS. J, Cunha RA, Prediger RD. Treadmill Exercise Attenuates L-DOPA-Induced Dyskinesia and Increases Striatal Levels of Glial CellDerived Neurotrophic Factor (GDNF) in Hemiparkinsonian Mice. Mol Neurobiol. 2019;(56):2944-51.

40. Schonecker M. Paroxysmal dyskinesia as the effect of megaphen. Nervenarzt. 1957;(28):550-3.

41. Faurbye A, Rasch PJ, Petersen PB, Brandborg G, Pakkenberg H. Neurological Symptoms in Pharmacotherapy of Psychoses. Acta Psychiatr Scand. 1964;(40):10-27.

42. Waddington J L. Spontaneous orofacial movements induced in rodents by very long-term neuroleptic drug administration: phenomenology, pathophysiology and putative relationship to tardive dyskinesia. Psychopharmacology. 1969; (101):431-47.

43. Wolf MA, Yassa R, Llorca PM. Neuroleptic-induced movement disorders: historical perspectives. Encephale. 1993; (19):657-61.

44. Tarsy D, Lungu C, Baldessarini RJ. Epidemiology of tardive dyskinesia before and during the era of modern antipsychotic drugs. Handb Clin Neurol. 2011;(100):601-16.

45. Tarsy D, Baldessarini RJ. Epidemiology of tardive dyskinesia: is risk declining with modern antipsychotics? Mov Disord. 2006;(21):589-98.

46. Kim J, Macmaster E, Schwartz TL. Tardive dyskinesia in patients treated with atypical antipsychotics: case series and brief review of etiologic and treatment considerations. Drugs Context. 2014;(3):212-59.

47. Mahmoudi S, Levesque D, Blanchet PJ. Upregulation of dopamine D3, not D2, receptors correlates with tardive dyskinesia in a primate model. Mov Disord. 2014; (29): 112533.

48. Strassnig M, Rosenfeld A, Harvey PD. Tardive dyskinesia: motor system impairments, cognition and everyday functioning. CNS Spectr. 2018(23):370-7.
49. Strassnig M, Brar JS, Ganguli R. Low cardiorespiratory fitness and physical functional capacity in obese patients with schizophrenia. Schizophr Res. 2011(126):103-9.

50. Stacy M, Cardoso F, Jankovic J. Tardive stereotypy and other movement disorders in tardive dyskinesias. Neurology. 1993(43):937-41.

51. Yassa R, Jones BD. Complications of tardive dyskinesia: a review. Psychosomatics. 1985;(26):305-13.

52. Simpson GM, Shrivastava RK. Abnormal gaits in tardive dyskinesia. Am J Psychiatry. 1978;(135):865.

53. Yassa R. Functional impairment in tardive dyskinesia: medical and psychosocial dimensions. Acta Psychiatr Scand. 1989;(80):64-7.

54. Lauterbach EC, Singh H, Simpson GM, Morrison RL. Gait disorders in tardive dyskinesia. Acta Psychiatrica Scand. 1990;(82):267.

55. Montero-Odasso M, Verghese J, Beauchet O, Hausdorff JM. Gait and cognition: a complementary approach to understanding brain function and the risk of falling. J Am Geriatr Soc. 2012;(60):2127-36.

56. Tinetti ME, Speechley M, Ginter SF. Risk factors for falls among elderly persons living in the community. N Engl J Med. 1988;(319):1701-07.

57. Verghese J, Mahoney J, Ambrose AF, Wang C, Holtzer R. Effect of cognitive remediation on gait in sedentary seniors. J Gerontol A Biol Sci Med Sci. 2010;(65):1338-43.

58. Casagrande SCB, Cury RG, de Lima-Pardini C, Coelho DB, Souza CO, Ghilardi GS, et al. Dramatic improvement of tardive dyskinesia movements by inline skating. Neurology. 2017;(89):211-13.

59. De Hert M, Correl CU, Boves J, Cetkovich-Bakmas M, Cohen D, Asai I, et al. Physical illness in patients with severe mental disorders. I. Prevalence, impact of medications and disparities in health care. World Psychiatry. 2011;10:52-77.

60. Stubbs B. Physical illness in patients with severe mental disorders. World Psychiatry 2013;(10):234-45.

61. Stubbs B, Koyanagi A, Schuch F, Firth J, Rosenbaum S, Gaughran F, et al. Physical Activity Levels and Psychosis: A Mediation Analysis of Factors Influencing Physical Activity Target Achievement Among People Across 46 Low- and Middle-Income Countries. Schizophr Bull. 2017; (43):536-45.

62. Methapatara W, Srisurapanont M. Pedometer walking plus motivational interviewing program for Thai schizophrenic patients with obesity or overweight: a 12-week, randomized, controlled trial. Psychiatry Clin Neurosci. 2011; (65):374-80.

63. Browne J, Penn DL, Battaglini CL, Ludwig K. Work out by Walking: A Pilot Exercise Program for Individuals With Schizophrenia Spectrum Disorders. J Nerv Ment Dis. 2016; (204):651-7.

64. Wu MH, Lee CP, Hsu SC, Chang CM, Chen CY. Effectiveness of high-intensity interval training on the mental and physical health of people with chronic schizophrenia. Neuropsychiatr Dis Treat. 2015;(11):1255-63.

65. Aguiar Jr AS, Araújo AL, da Cunha TR, Speck AE, Zuleide MI, de Mello N, et al. Physical exercise improves motor and 
short-term social memory deficits in reserpinized rats. Brain Res Bull. 2009;(79):452-7.

66. Teixeira AM, Reckziegel P, Müller L, Pereira RP, Roos DH, Rocha JBT, et al. Intense exercise potentiates oxidative stress in striatum of reserpine-treated animals. Pharmacol Biochem Behav. 2009;(92):231-5.

67. Teixeira AM, Trevizol F, Colpo G, Garcia SC, Charão M, Pereira RP, et al. Influence of chronic exercise on reserpineinduced oxidative stress in rats: behavioral and antioxidant evaluations. Pharmacol Biochem Behav. 2008;(88):465-72.

68. Zukerman E, Vilanova LC, Serafico J. Familial paroxysmal choreoathetosis. Report of 2 cases in one family. Ar. Neuropsiquiatr. 1983;(41):373-6.

69. Lance JW. Familial paroxysmal dystonic choreoathetosis and its differentiation from related syndromes. Ann Neurol.1977;(2):285-93.

70. Berkovic SF. Paroxysmal movement disorders and epilepsy: links across the channel. Neurology. 2000;(55):169-170.

71. Weber YG, Kamm C, Suls AK, Kempfle J, Kotschet K, Schüle R, Wuttke TV, et al. Paroxysmal choreoathetosis/ spasticity (DYT9) is caused by a GLUT1 defect. Neurology. 2011;(77):959-64.

72. Shirley TL, Rao LM, Hess EJ, Jinnah HA. Paroxysmal dyskinesias in mice. Mov Disord. 2008;(23):259-64.

73. Dale RC, Melchers A, Fung VSC, Grattan-Smith P, Houlden H, Earl J, et al. Familial paroxysmal exercise-induced dystonia: atypical presentation of autosomal dominant GTPcyclohydrolase 1 deficiency. Dev Med Child Neurol. 2010; (52):583-6.

74. Liu Q, Qi Z, Wan XH, Li JY, Shi L, Lu Q, et al. Mutations in PRRT2 result in paroxysmal dyskinesias with marked variability in clinical expression. J Med Genet. 2012;(49):79-82.

75. Roubergue A, Roze E, Vuillaumier-Barrot S, Fontenielle MJ, Méneret A, Vidailhet M, et al. The multiple faces of the ATP1A3-related dystonic movement disorder. Movement disorders . J Mov Disord Society. 2013;(28):1457-9.

76. Friedman JR, Méneret A, Chen DH, Trouillard O, Vidailhet $\mathrm{M}$, Raskind $\mathrm{WH}$, et al. ADCY5 mutation carriers display pleiotropic paroxysmal day and nighttime dyskinesias. Movement disorders : J MovDisord Society. 2016;(31):1478.

77. Münchau A, Valente EM, Shahidi GA, Eunson LH, Hanna MG, Quinn NP, et al. A new family with paroxysmal exer- cise induced dystonia and migraine: a clinical and genetic study. J Neurol Neurosurg Psychiatry. 2000;(68):609-14.

78. Neville BG, Besag FM, Marsden CD. Exercise induced steroid dependent dystonia, ataxia, and alternating hemiplegia associated with epilepsy. J Neurol Neurosurg Psychiatry. 1998;(65):241-4.

79. Guerrini R, Bonanni P, Nardocci N, Parmeggiani L, Piccirilli M, Fusco M, et al. Autosomal recessive rolandic epilepsy with paroxysmal exercise-induced dystonia and writer's cramp: delineation of the syndrome and gene mapping to chromosome 16p12-11.2. Ann Neurol. 1999; (45):344-52.

80. Bozi M, Bhatia KP. Paroxysmal exercise-induced dystonia as a presenting feature of young-onset Parkinson's disease. Mov Disord. 2003;(18):1545-47.

81. Khan Z, Jinnah HA. Paroxysmal dyskinesias in the lethargic mouse mutant. J Neurosci. 2002;(22):8193-200.

82. Zorzi G, Conti C, Erba A, Granata T, Angelini L, Nardocci $\mathrm{N}$, et al. Paroxysmal dyskinesias in childhood. Pediatr Neurol. 2003;(28):168-72.

83. Zorzi G, Castellotti B, Zibordi F, Gellera C, Nardocci N. Paroxysmal movement disorders in GLUT1 deficiency syndrome. Neurology. 2008;(71):146-8.

\section{Corresponding author}

Dra. Ana Elisa Speck. Universidade Federal de Santa Catarina, UFSC, Departamento de Farmacologia, Centro de Ciências Biológicas, Bloco D, 88049-900, Florianópolis, SC, Brasil.

E-mail: anaespeck@gmail.com.

Manuscript received on April 12, 2020

Manuscript accepted on June 8, 2020

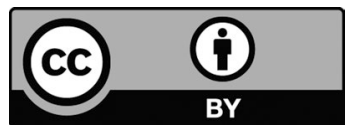

Motriz. The Journal of Physical Education. UNESP. Rio Claro, SP, Brazil - eISSN: 1980-6574 - under a license Creative Commons - Version 4.0 